NBER WORKING PAPER SERIES

\title{
ADDRESSING THE NEEDS OF UNDER-PREPARED STUDENTS IN HIGHER EDUCATION: DOES COLLEGE REMEDIATION WORK?
}

\author{
Eric P. Bettinger \\ Bridget Terry Long \\ Working Paper 11325 \\ http://www.nber.org/papers/w11325
NATIONAL BUREAU OF ECONOMIC RESEARCH 1050 Massachusetts Avenue \\ Cambridge, MA 02138 \\ May 2005
}

The authors' affiliations are Case Western Reserve University, Department of Economics and Harvard University, Graduate School of Education, respectively. Send comments to bettinger@cwru.edu and longbr@gse.harvard.edu. The authors are grateful for helpful suggestions from seminar participants at the National Bureau of Economic Research (NBER) Education Program Meeting, Cornell Higher Education Research Institute (CHERI), University of Michigan, Case Western Reserve University, and the University of Virginia. The authors thank the Ohio Board of Regents for their support during this research project. Rod Chu, Darrell Glenn, Robert Sheehan, and Andy Lechler provided invaluable help with the data. In addition, the Lumina Foundation provided crucial funding to aid in this research. Erin Riley and Cathy Wegmann provided excellent research assistance. All opinions and mistakes are our own. The views expressed herein are those of the author(s) and do not necessarily reflect the views of the National Bureau of Economic Research.

(C)2005 by Eric P. Bettinger and Bridget Terry Long. All rights reserved. Short sections of text, not to exceed two paragraphs, may be quoted without explicit permission provided that full credit, including $\odot$ notice, is given to the source. 
Addressing the Needs of Under-Prepared Students in Higher Education: Does College Remediation Work?

Eric P. Bettinger and Bridget Terry Long

NBER Working Paper No. 11325

May 2005

JEL No. I2, H4, C2

\begin{abstract}
Each year, thousands of students graduate high school academically unprepared for college. As a result, approximately one-third of entering postsecondary students require remedial or developmental work before entering college-level courses. However, little is known about the causal impact of remediation on student outcomes. At an annual cost of over $\$ 1$ billion at public colleges alone, there is a growing debate about its effectiveness. Who should be placed in remediation, and how does it affect their educational progress? This project addresses these critical questions by examining the effects of math and English remediation using a unique dataset of approximately 28,000 students. To account for selection biases, the paper uses variation in remedial placement policies across institutions and the importance of proximity in college choice. The results suggest that students in remediation are more likely to persist in college in comparison to students with similar test scores and backgrounds who were not required to take the courses. They are also more likely to transfer to a higher-level college and to complete a bachelor's degree.
\end{abstract}

Eric P. Bettinger

Weatherhead School of Management

Peter B. Lewis Building, RM 266

Case Western Reserve University

Cleveland, OH 44106-7235

and NBER

bettinger@cwru.edu
Bridget Terry Long

Graduate School of Education

Harvard University

Gutman Library 465

Appian Way

Cambridge, MA 02138

and NBER

longbr@gse.harvard.edu 


\section{Introduction}

Although approximately two-thirds of recent high school graduates enter college each year, many of these students are unprepared academically for college-level material (Greene and Foster, 2003). In some cases, academic deficiencies are so severe that colleges choose to expel the students. For instance, during the fall of 2001, the California State University system "kicked out more than 2,200 students - nearly 7 percent of the freshman class - for failing to master basic English and math skills" (Trounson, 2002). However, the most common response has been to place ill-prepared students in remedial courses. ${ }^{1}$ Because the average college student attends a nonselective institution to which he or she is almost assured admission, the remediation placement exam taken when first arriving on campus has become the key academic gate-keeper to postsecondary study. ${ }^{2}$ In 2001 , colleges required nearly one-third of first-year students to take remedial courses in reading, writing, or mathematics (NCES, 2003).

Remediation proponents suggest that the courses help under-prepared students gain the skills necessary to excel in college and may serve as a tool to integrate students into the school population (Soliday, 2002). In addition, by placing weaker students into separate courses, remediation allows colleges to protect institutional selectivity, regulate entry to upper level courses, and generate enrollment, particularly in English and math departments. However, by increasing the number of requirements and extending the time to degree, remediation may negatively impact student outcomes such as persistence, major choice, and eventual labor market returns. ${ }^{3}$ Moreover, the cost of remediation is significant. In Ohio, public colleges spent approximately $\$ 15$ million teaching 260,000 credit hours of high school-level courses to freshmen in 2000; another $\$ 8.4$ million was

\footnotetext{
${ }^{1}$ The literature defines "remediation" as coursework that is retaken while classes that focus on new material are termed "developmental." In this paper, we will refer to both types of below-college-level courses as remedial. This also includes "basic-skills training" and "nontraditional coursework" but not ESL courses.

${ }^{2}$ The bulk of remediation is provided by non-selective public institutions, the point of entry for 80 percent of fouryear students and virtually all two-year students. Four-fifths of public four-year colleges and 98 percent of community colleges provide remedial courses.

${ }^{3}$ Nationally and in Ohio, most colleges offer general institutional credit for remedial courses but this credit often does not count towards a degree. Additionally, over four-fifths of campuses restrict enrollment in at least some college-level classes until remediation is complete (NCES, 2003; LOEO, 1995). These requirements may restrict students' course schedules and impede the ability to major in certain areas.
} 
spent on older students (OBR, 2001). In addition, the 20,000 freshmen in the courses paid \$15 million in tuition for their remediation as well as used financial aid resources and sacrificed foregone wages. With an estimated annual cost of over $\$ 1$ billion nationally at public colleges (Breneman and Haarlow 1997), many states question whether and, if so, how remediation should be offered. Remedial courses are "not allowed" at public institutions in two states, and at least eight states restrict remediation to two-year colleges. Other states have imposed or are considering limits on the government funding of remedial coursework (ESC, 2003). ${ }^{4}$ Finally, critics question whether the courses remove the incentive for students to adequately prepare while in high school.

Despite the extensive use of remedial courses to address academic deficiencies, little is known about their effects on subsequent student performance in college. Who should be placed in remediation, and how does it affect their educational progress? Most states and colleges do not have exit standards for remedial courses and do not perform systematic evaluation of their programs (Crowe, 1998; Weissman, Bulakowski, and Jumisko, 1997). There are also no current benchmarks by which to judge the success of higher education's remediation efforts (Ohio Board of Regents, 2001). Moreover, two reviews of the literature on remedial and developmental education found the bulk of studies to be seriously flawed methodologically (O'Hear and MacDonald, 1995; Boylan and Saxon, 1999). A simple comparison of students placed in remediation to those who are not is inherently flawed due to differences between the students. For example, NCES (1996) suggests that freshmen enrolled in remedial classes are less likely to persist into their second year, but this evidence does not control for student ability or possible movement across colleges. As noted by Phipps (1998), “conjecture and criticism have filled the void created by the lack of basic information."

This paper addresses this major hole in the literature. Using data from the Ohio Board of Regents (OBR), we track approximately 28,000 full-time, traditional-age freshmen at public college

\footnotetext{
${ }^{4}$ For example, Florida and Illinois restrict remediation to two-year colleges, and the CUNY system came under fire in 1998 for implementing a similar restriction. The California State University system imposes a one-year limit on remedial work, while Texas, Tennessee, and Utah have or are considering similar restrictions.
} 
over five years to investigate the impact of remediation on college performance and persistence. To avoid the inherent biases, we use variation in remedial placement policies across institutions and the importance of proximity in college choice. Together, these two sources of variation provide an exogenous predictor of the likelihood of remediation. In essence, we compare observationally-alike students who attend different colleges, due to proximity, and therefore, have varying experiences with remediation. Because our estimation strategy relies upon students for whom the probability of remediation differs according to the college they attend, the analysis estimates a local average treatment effect (LATE). The results suggest that remediation does have a positive impact on the college outcomes of under-prepared students. Students placed in remediation are more likely to persist in college in comparison to students with similar test scores and backgrounds who were not required to take the courses. They are also more likely to transfer to a higher-level or more selective college and to complete a four-year degree. ${ }^{5}$

\section{The Supply and Demand of Remediation}

\section{Context of the Study: Ohio Students and Colleges}

This study focuses on traditional-age (18 to 20 years old) college undergraduates who entered public colleges in Ohio as first-time freshmen during the fall of 1998. The sample is limited to fulltime students who took the ACT and either attended a four-year college or signified the intent to complete a four-year degree on their community college application. ${ }^{6}$ With longitudinal information from college transcripts, applications, and standardized tests reports with the accompanying student

\footnotetext{
${ }^{5}$ These results differ from earlier work that focused on math remediation at four-year colleges. The previous analysis tracked students for only four years and explored the possible signaling function of remediation in terms of re-sorting under-prepared students to less selective colleges. In contrast, this paper focuses on the effects of remediation for students on the margin of needing the courses at both four-year and two-year colleges; it reports a local average treatment effect.

${ }^{6}$ Half of traditional-age students (35 percent of all students) denote on their community college application intent to get a four-year degree or transfer to a four-year institution. The ACT requirement further emphasizes that this sample had some four-year intent as it is not required for admission. Technical colleges are excluded.
} 
surveys, the analysis tracks these students over five years. ${ }^{7}$ Although this paper focuses on students in Ohio, the results should have external validity due to patterns of enrollment and remediation similar to national averages (Mortenson, 2002; NCES, 1996). Moreover, Ohio has the fifth largest public higher education system reflecting a mixture of selective and nonselective institutions spread geographically across the state. Finally, because only 12 percent of students take remedial courses at private, four-year colleges (NCES, 2003), the focus on public colleges is likely to give an accurate picture of the general effects of remediation.

Table 1 provides summary statistics of the data. ${ }^{8}$ As is typical in higher education, the sample is slightly more female, and the percentage of the sample that is African-American and Asian is similar to national college proportions (Hispanic students are underrepresented). Twenty-two and 14 percent took math and English remedial courses, respectively. Due the sample restrictions discussed above, these proportions are smaller than figures for the entire cohort of students who entered that fall. In terms of student outcomes, 40 percent of students were no longer found in the Ohio public higher education system after five years and therefore are considered dropouts. Nearly 44 percent had completed a bachelor's degree after five years leaving 16 percent still pursuing their studies within the system. Given the system-wide nature of the data, we can accurately track students across schools and include individuals who may have continued their educations or completed their degrees at different schools from the ones they originally entered. However, the data do not include students who transfer to private colleges or out of the state. The potential measurement error is likely to be very small since the percentage of students thought to transfer to such schools is a small fraction of the total number of observed dropouts (Bettinger and Long, 2004).

\footnotetext{
${ }^{7}$ Most students in Ohio take the ACT exam. The records include the highest score of the student and his or her most recent responses to the ACT survey, which includes self-reported information on high school preparation and performance as well as the intended plan of study in college.

${ }^{8}$ To be included in the sample, students must have had valid zip code information, and colleges needed to have clear records of which courses were considered remedial and which were not during the sample period. The sample excludes two schools due to the inability to identify which courses were remedial in 1998-99 (University of Cincinnati and Kent State University).
} 


\section{Placement into Remediation}

In Ohio, all but one of the public colleges offer remedial courses to entering freshmen. ${ }^{9}$ However, colleges in the state are free to set their own admissions, placement, and remediation policies (LOEO, 1995). All schools require entering freshmen to take placement exams, but the placement instruments vary by institution with colleges using different combinations of ACT and SAT scores, high school transcripts, assessment exams, and institutional-developed subject-area tests. $^{10}$ There is also a great deal of variation across institutions as to what constitutes a remedial course. While there are statewide standards to distinguish between remedial and college-level work, given the autonomy of public colleges in Ohio, institutions differ in how they interpret these standards at the campus level. A survey on placement mechanisms and cut-off scores in Ohio found significant differences in the level of performance required for placement into their college-level writing courses. For example, cut-off scores for placement into writing remediation varied from 17 to 20 for the ACT, 410 to 580 for the SAT, and 26 to 44 for the ASSET test (SHERAC, 1997).

Therefore, a student who might be placed into college-level courses at some Ohio colleges would be put in remediation at others. This variation across institutions is central to our estimation strategy.

Remediation policies could vary across colleges for a number of reasons. First, the preferences of the administration are likely to influence the role of remediation at a school. For example, one four-year university decided to eliminate remediation after a change in college leadership. Students requiring remediation are now referred to a local community college (Sheehan, 2002). The preferences of the departments responsible for remedial courses are also likely to be important and could impact which exam is used or the relative weight given to high school preparation in determining placement. Finally, cost could affect remediation policies. If the cost of remediation differs across schools, then they may cause policies to vary. Particularly over time, as

\footnotetext{
${ }^{9}$ The exception is Central State University. Miami University also sends remedial students to satellite campuses.

${ }^{10}$ The assessment exams include the Computerized Adaptive Placement Assessment and Support Systems (COMPASS) and the Assessment of Skills for Successful Entry and Transfer (ASSET), both published by ACT, Inc. Each consists of a variety of tests to measure students' skill levels. For example, the ASSET exam is a written exam with as many as 12 subsections, including in depth assessment of students' writing, numerical, and reading skills.
} 
college budgets become more or less constrained, institutions may be more or less willing to spend money on remediation. While the political economy and secondary schools of the surrounding area might also be important in determining the role of remediation at a college, as shown below, the characteristics of the local community are not related to the cutoffs for placement into remediation.

The first major group of students in remedial education is under-prepared recent high school graduates, many of whom exit secondary school without grade-level competency or the proper preparation for college-level material. In our sample, 37 percent of first-year students under the age of 19 fit into this category having graduated from high school without a college-prep curriculum (OBR, 2002). Studies have found that students who complete an academic core curriculum in high school are half as likely to need remediation in college in comparison to other students (OBR, 2002; Hoyt and Sorensen, 1999). However, 25 percent of those with a known core high school curriculum still required remediation (OBR, 2002). In addition to recent high school graduates, a substantial number of adult students enroll in developmental courses along with recent immigrants. Nationally, about 27 percent of remedial students are over the age of 30 (IHEP, 1998).

Table 1 summarizes the characteristics of students placed into remediation versus those who are not. As expected, students placed into remediation had lower ACT scores and high school GPAs. For example, students placed in math remediation scored a mean of 17.4 on the math section of the ACT while students who did not take the classes scored 23.3 (a similar gap, 15.8 versus 22.8 , is found for English remediation). A simple comparison of the outcomes of students placed into remediation and those who are not suggests that remedial students had worse educational outcomes. After five years, a larger proportion of them dropped out of college without a degree (65.2 for those in math remediation versus 30.8 percent) and fewer of them completed a baccalaureate degree (18.1 for those in math remediation versus 53.3 percent). However, this comparison does not take into account differences in the sample of remediated and non-remediated students. The next section discusses our methodology for overcoming this issue of selection. 


\section{Empirical Framework using Variation Across-Colleges}

\section{Biases in the Study of Remediation}

To understand the impact of remedial education policies, we compare the outcomes of students placed in remediation to those who are not. However, selection issues preclude a straightforward analysis. The first major concern is ability bias. Lower-ability, less-prepared students are more likely to be placed in remediation. Furthermore, even in the absence of remediation, they are less likely to persist and complete a degree. A second concern is college choice. Enrollment in a particular college may be an endogenous choice reflecting both student ability and preferences about remediation. For example, a student wishing to avoid remediation might choose a college with a very low placement cutoff.

To address these issues, we construct a two-part instrumental variable (IV). First, to deal with ability bias, we use variation in college remediation policies. As noted above, schools differ in their methods of assignment into remediation. Therefore, two identical students attending different schools face dissimilar probabilities of remediation based on each college's policy. Figure 1 displays the degree of variation in placement policies using ACT score as a predictor of placement into remediation. Each row corresponds to a different group of colleges. ${ }^{11}$ The left-hand graphs show the distribution of student body ACT scores at each set of institutions. The right-hand graph shows likelihood functions for the ACT remediation cutoffs as determined using a series of probit models for each possible ACT score:

$$
\operatorname{Pr}(\text { Remediation })=\mathrm{f}(\mathrm{a}+\mathrm{b} * \mathrm{I}(\mathrm{ACT}>\mathrm{J})+\mathrm{e})
$$

where $\mathrm{I}(\mathrm{ACT}>\mathrm{J})$ is an indicator for whether the ACT score of student $i$ is greater than $\mathrm{J}$, and $\mathrm{J}$ varies over the possible range of the ACT math score (1-36). To the extent that colleges use the ACT score to assign remediation, these likelihood plots show a spike at the most likely cutoff value used by an

\footnotetext{
${ }^{11}$ Selective public institutions in Ohio require a certain academic standard but are not considered highly selective by national norms. Nonselective four-year colleges may require the ACT but are open admissions schools.
} 
individual school. ${ }^{12}$ For each set of schools except the selective universities, while the distribution of student body ACT scores looks similar across schools (left-hand graph), the remediation cutoffs in the right-hand column show much greater heterogeneity. For example, the student bodies look similar among nonselective, four-year public institutions (middle row), but the predicted ACT cutoffs vary across these institutions from a score of 14 to 23 . Hence, while all the four-year and two-year nonselective colleges in the state serve similar-ability students (i.e. comparing the left-hand graphs of the first two rows), they use different thresholds to determine placement into remediation (the righthand graph). As expected, the ACT scores of students at the selective, four-year universities are higher, but as explained below, only students at these schools who might plausibly be placed in remediation are used in the main results. The scores of these students are much more similar to those of students at nonselective colleges.

The second part of the instrument uses proximity as an exogenous predictor to deal with concerns of endogenous college choice. Previous research has shown that students are more likely to attend one school over another depending on how close the colleges are to their homes (Rouse, 1995; Card, 1995). In fact, by design, most residents in Ohio are within thirty miles of a college campus in order to facilitate access (OBR, 2001), and the median distance from a student's home to their college is only 26 miles. In summary, we assume that proximity is related to the school chosen, and therefore the remediation policy the student faces, but it is not related to outcomes such as persistence in college. Our instrument thereby combines both the likelihood of a student choosing a given institution and the likelihood of being placed into remediation at that college. If distance exogenously predicts the college of attendance, and each college has a different remediation policy, then the interaction of these variables exogenously predicts remediation. ${ }^{13}$

\section{The Construction of the Instrumental Variable}

\footnotetext{
${ }^{12}$ A similar methodology is used in Kane (2003).

13 The results are similar using an instrument based on the remediation probability at the nearest school.
} 
To approximate the likelihood that an individual will attend a specific college, we estimate the probability of attendance based on distance conditional on the individual choosing a public college. The predicted probabilities are determined using a conditional logistic regression model, a framework that has been used to study college choice as well as the selection between travel modes and occupations. ${ }^{14}$ The conditional logit model is made up of $j$ equations for each individual $i$, with each equation describing one of the college alternatives. The dependent variable, signifying the choice of the individual, equals one for the alternative that was chosen, and the model estimates the impact of distance on the probability of enrollment at each of the colleges relative to all the other alternatives. ${ }^{15}$ Under the assumption that the $\varepsilon_{\mathrm{ij}}$ 's are independent and identically distributed with the extreme value distribution, we get the conditional logit functional form as shown in equation (1):

$$
\begin{aligned}
& \operatorname{Pr}\left(Y_{i}=j\right)=\frac{e^{B^{\prime} X_{i j}}}{\sum_{j} e^{B^{\prime} X_{i j}}} \\
& B^{\prime} X_{i j}=\alpha+\beta \mathrm{S}_{\mathrm{j}}+\gamma_{1} \mathrm{D}_{\mathrm{ij}}+\gamma_{2} \mathrm{D}_{\mathrm{ij}}^{2}+\gamma_{3} \mathrm{D}_{\mathrm{ij}}^{3}+\gamma_{4} \mathrm{D}_{\mathrm{ij}} \mathrm{L}_{\mathrm{j}}+\varepsilon_{i j}
\end{aligned}
$$

where $S_{j}$ is a series of fixed effects for each college, $D_{i j}$ is the distance that student $i$ lives from university $j$ along with,$D^{2}{ }_{i j}$ and $D^{3}{ }_{i j}$, distance squared and cubed, and $D_{i j} L_{j}$, interactions between distance and the level of the college. ${ }^{16}$ The conditional logit estimates suggest that our sample was much less likely to choose a college the farther away it was from their residence with a coefficient of -2.66 per 100 miles (the results are not marginal probabilities) and a Z-statistic of 51.91. This reflects that fact that 75 percent of the sample attended a college within 100 miles of their home, and nearly 60 percent attended a college within 50 miles. Using the estimated coefficients, we calculate the probability of enrollment at each college.

The second part of the IV predicts the likelihood of remediation. While using placement scores would be ideal, in their absence we use information on the characteristics of students placed in and out of remediation at each school. The likelihood of taking math remediation is modeled as a

\footnotetext{
${ }^{14}$ For an application of the conditional logit to college choice, see Long (2004).

${ }^{15}$ Distance is calculated using the zip code on the college application and the zip code of the college.

${ }^{16}$ If the Independence of Irrelevant Alternatives (IIA) condition is met, the estimates will be consistent even if the decision to attend college at all is endogenous. See Long (2004) for discussion.
} 
probit controlling for student characteristics such as math ACT score, the score squared, high school overall GPA, high school math GPA, the number of math classes taken in high school, race, gender, age, the type of high school attended, family financial background, postsecondary degree intent, and similar variables for those submitting the SAT. We also saturate the model with dummy variables for each college and separate interactions between the college dummy and the student's math ACT, math grades in high school, and years of math. ${ }^{17}$ Using these coefficients, we then predict the likelihood of math remediation for each student at each college. The same methodology was followed to predict the likelihood of English remediation (replacing math scores, grades, and semesters of courses with verbal scores and English grades and courses in high school). Likelihood ratio tests reject the hypothesis that the coefficients on the college dummy variables are the same. Therefore, institutional remediation rules do not appear to be equal and attending a different college could dramatically change the likelihood that an individual student would be placed into remediation.

One remaining concern with endogeneity relates to the role of local high schools and communities. As discussed above, colleges may set their remediation policies in response to the skill level of local graduates or feeder schools. If so, our empirical strategy using proximity is in fact endogenous. The appendix displays analyses of whether there is indeed a relationship between the estimated ACT cutoff for remediation and the characteristics of the college and its area high schools. The regression models compare the estimated ACT cutoff for remediation to the characteristics of high schools within 10 miles and 30 miles. However, none of the variables are statistically significant. Two additional specifications focus only on the nearby, low-performing high schools. Graduates of these schools are very likely to need remediation, and so they may be more likely to influence college remediation policies. However, again, none high school characteristics seem to

\footnotetext{
${ }^{17}$ By estimating this as one large model with dummy variables for each college, we hold constant across schools the role of student demographic characteristics (race, gender, and age), family income, type of high school, and type of high school degree in determining the probability of remediation. The probability is only related to the math ACT score, years and grades in high school math, and the general placement threshold of the school.
} 
explain the placement cutoffs. Therefore, local communities do not appear to influence remediation policies, and proximity remains an exogenous predictor of the likelihood of remediation.

We combine the probabilities of attendance and of remediation to build our instrument for remediation as shown in equation (2):

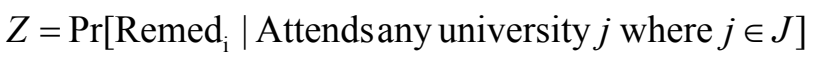

$$
\begin{aligned}
& =\sum_{\mathrm{j} \in \mathrm{J}} \operatorname{Pr}\left[\operatorname{Remed}_{\mathrm{i}} \mid \text { Attends university } j\right] \operatorname{Pr}[\text { Attends university } j \mid \text { Attends any university } j \in J]
\end{aligned}
$$

Table 2 provides an example of the instrument for an actual student. Column 1 shows the predicted probabilities of attendance at each of the campuses (calculated using the conditional logistic model). As shown for campus 28 , the school the student actually chose, the probability of attendance based on distance was actually the second highest of the 45 possible institutions (17.1 percent). Column 2 uses the individual's test scores, high school preparation, and background characteristics to predict the probability of taking a remedial course at each campus. Finally, column 3 is the product of those two probabilities, the probability of attending each school weighted by the probability of remediation at that school. The instrument is constructed by summing all the values in column 3 . The final instrument suggests that the student has a 12.4 percent chance of being in remediation. ${ }^{18}$ In our results of the first stage equation for math remediation, the coefficient of the instrument is 1.12 with a standard error of 0.0405 , thereby making it significant at the 99 percent level. In a similar fashion, the coefficient on the IV for English remediation is 1.23 with a standard error of 0.0381 .

\section{Estimating the Effects of Remediation and the Local Average Treatment Effect (LATE)}

The effects of remediation are measured using the regression model shown in equation (3):

$$
\text { Outcome }_{i}=\alpha+\beta \text { Remed }_{i}+\gamma \mathrm{X}_{\mathrm{i}}+\mathrm{e}
$$

\footnotetext{
${ }^{18}$ Another way to view our instrument is as a correction in the probability of remediation based on distance to schools with different policies. If we were to estimate a regression of the likelihood of remediation on all covariates, we could generate predicted values for each person. If we ran similar regressions including our instrument, we would generate other set of predicted values. The difference between these two predicted values is the correction based on distance and different remediation policies and is the source of variation we use in this paper.
} 
where $X$ is a matrix of individual characteristics that may influence both assignment to remediation and students' outcomes. The model controls for race, gender, age, ACT composite score, ACT math (or English and Reading) score, high school GPA, high school rank, family income, high school types, semesters of high school math (or English), high school grades in math (or English), and type of high school degree (dummy variable for GED). Remediation enters as a dummy variable equal to one if the person enrolled in any remedial course. To test whether there are different effects for math versus English remediation, separate estimates by subject are provided. The outcomes are measured for five school years from Fall 1998 to Spring 2003. Students are considered "drop outs" if they are no longer at any public, Ohio college at the end of the time period and have not received a four-year degree. Students who have "transferred down" are at a less selective or lower-level college (university branch campuses are considered less selective than four-year colleges). Students who have "transferred up" went to a more selective or higher-level college. Unlike other studies, students who transferred to other colleges are not considered dropouts due to our ability to track students. It is important to note that this is the "intention to treat" effect as some students placed in remediation never complete the courses.

Our estimation strategy and results rely on students for whom the probability of remediation differs according to the college they attend. Therefore, the estimates are not reflective of students who would have either always or never been put in remediation. Keeping these students in the sample would skew the results. ${ }^{19}$ The target sample is instead marginal remediation students for whom it is questionable whether they do or do not need remediation. This margin may be especially important for the current debate as states and colleges try to determine ways to reduce and/or shift remedial services without terminating them completely.

\footnotetext{
${ }^{19}$ When estimating the results using the full sample, students who would never or always be placed in remediation effectively drop out of the sample due to lack of variation in the treatment. Therefore, this restriction mainly affects students with a profile in which they are rarely placed in remediation or rarely place out. However, because the aim of this paper is to understand the effects on students truly on the margin of needing remediation, we chose to exclude these outliers and rely on the local average treatment effect.
} 
To get the Local Average Treatment Effect (LATE), we imposed the following sample limitations. First, we dropped students who had less than a 25 percent chance of remediation at the school with the $90^{\text {th }}$ percentile placement threshold (i.e. one of the most stringent schools; with a high threshold). ${ }^{20}$ In other words, students who had only a small probability of remediation under very rigorous standards are assumed to rarely be placed in remediation. Second, students who had at least a 25 percent chance of remediation at the school with the $10^{\text {th }}$ percentile placement threshold (i.e. one of the most lenient schools; with the low threshold) were also dropped. We assumed these students would almost always be placed into remediation regardless of the school policy. Finally, we dropped students who did not have at least a 25 percentage-point difference between the $90^{\text {th }}$ and $10^{\text {th }}$ percentile remediation probabilities across the schools; this removes students without sufficient variation in the probability of remediation. ${ }^{21}$ Because there are other possible ways to define the LATE group, the results below were also estimated using different cutoffs. For instance, rather than the 25 percent cutoffs used in the above definition, 33 percent cutoffs were used. The results are robust to these different definitions. Additionally, results using the full sample of students may be thought of as a lower bound of the LATE: the full sample is essentially equivalent to using the least restrictive possible definition of the LATE.

The last two columns of Table 1 provide summary statistics of the sample used to estimate the LATE. Using this definition of the LATE group is very inclusive of many students, and the results apply to a large proportion of college students. The sample size drops only by a third for the Math Remediation group (slightly larger for the English remediation group) suggesting that variation in the remediation cutoff is important for the majority of students. In comparison to the full sample, fewer students are from the selective four-year colleges, but these students still make up the largest

\footnotetext{
${ }^{20}$ So that the definition of the LATE sample is not driven by a single, outlier college, the $90^{\text {th }}$ percentile is used rather than the college with the highest overall placement threshold. Similarly, the $10^{\text {th }}$ percentile is used.

${ }^{21}$ Of the restrictions, the first (dropping students who would rarely be in remediation) and third (dropping students without much variation in their probability of remediation) are the most binding. These restrictions are also reinforcing: nearly all of the students dropped due to the first restriction also qualify to be dropped under to the third. Very few students would have been placed in remediation at the most lenient schools (the second restriction).
} 
group. The LATE samples also have lower average ACT scores than the full sample again suggesting that students at the top of the distribution who would never be placed in remediation have been dropped; students who would have always been in remediation have also been dropped, but there are fewer of them. For instance, the LATE sample for the math analysis does not include any student with a math ACT score of eleven or below, and many students with math ACT scores of 12, 13, and 14 are also excluded due to also having few years of preparation and/or low grades in high school math.

\section{The Effects of Math and English Remediation}

\section{The Overall Effects of Remediation}

This section discusses the impact of remediation on persistence, transfer behavior, and degree completion for similar students placed in and out of remediation. Tables 3 and 4 report the basic results of the impact of remediation on a variety of various outcomes using OLS and IV regression analysis. $^{22}$ The left panel displays results for the full sample while the right side focuses on the LATE. Means of the outcome variable are shown to aid in interpretation. Each coefficient under the OLS and IV columns represents a separate regression with controls for race, gender, age, ACT composite score, ACT math (or English and Reading) score, high school GPA, high school rank, family income, high school type, semesters of high school math (or English), high school grades in math (or English), and type of high school degree (dummy variable for GED).

The first thing that is obvious from the results is the difference between the OLS and IV results. As discussed above, a simple comparison of students in and out of remediation is likely to suggest negative effects due to important academic differences in the underlying populations. For instance, as shown in Table 3, students in math remediation are found to be 13.7 percent more likely to drop out and 10.8 percent less likely to complete a degree by Spring 2003 than students not in

\footnotetext{
${ }^{22}$ Some of the estimates have fewer then the total number of observations due to the fact that students at selective four-year cannot transfer up and students at community colleges cannot transfer down.
} 
remediation. However, when using the IV strategy to deal with such biases, these negative estimates disappear.

A second major pattern in the results is the difference between those estimated for the entire sample versus the LATE results. As discussed above, the estimation strategy relies upon the sample of students for whom the likelihood of remediation varies across schools. As would be expected, the results become stronger once focusing more finely on this marginal group. As shown in the IV column of results for the LATE sample, students in remedial math courses are nearly 10 percent less

likely to drop out than similar students. Likewise, remediated students are more likely to complete a bachelor's degree. As theory would predict, using more restrictive sample limitations to determine the LATE increases the positive estimated effects of remediation. For instance, when restricting the sample to students with at least a one-third chance (33 percent) of being placed into remediation at their most stringent school and less than one-third chance (33 percent) at their most lenient, math remediation is estimated to reduce the probability of dropping out by 13.5 percent (in comparison to a 9.6 percent reduction using the 25 percent cutoffs). Therefore, our original LATE results may be thought of as conservative estimates of the impact of remediation on marginal students.

Table 4 shows that similar impacts are found for English remediation in terms of persistence and degree completion. Focusing on the LATE IV results, students in English remediation are 9.7 percent less likely to drop out and 9.3 percent more likely to graduate by Spring 2003 than similar students. In addition, students in English remediation are 18.7 percent less likely to transfer to a lessselective or lower-level college.

\section{The Effects of Remediation by Student Ability}

While the previous tables suggest that remediation has a positive effect overall on student outcomes, the next part of the analysis tests whether the effect differs by ability level as measured by ACT score. Table 5 displays the results from including an interaction between the student's ACT score and the remediation dummy variable; the top panel has the results for math while the bottom 
focuses on English. Although the coefficients for math remediation suggest it has a detrimental impact on student outcomes (e.g. increasing the likelihood of stopping out and reducing degree completion), once the results are evaluated at the mean ACT math score, the results are similar those found above. For example, evaluated at the mean ACT math score of students in math remediation (mean 17.68), students in remedial math courses are 14.0 percent less likely to drop out of college by Spring 2003. As shown by the sign of the interaction, the beneficial effects of remediation on stopping out increase with the ACT score. Students with higher math ACT scores who are placed into remediation are also more likely to transfer up, finish their degree, and complete more total credit hours.

The results in the bottom half of the table are also similar to the earlier results once evaluated at the mean. Using a mean English ACT score of 15.66 for the group in remediation, the results suggest that they are 11.7 percent less likely to stop out of college by Spring 2003. The impact of English remediation on reducing the probability of dropping out also appears to increase with ability as shown by the negative sign on the interaction between the remediation dummy variable and the ACT English score. However, unlike for math remediation, the reverse is true for the other outcomes. While students in English remediation generally tend to complete more credit hours, are more likely to transfer up, and graduate within five years, this positive effect declines the higher the ACT score. Therefore, although math remediation appears to help higher ability students more overall, the impacts of English remediation by ability are more mixed. ${ }^{23}$

\section{The Effects of Remediation on Student Interest}

The final section of analysis examines whether the effects of remediation vary across students with different academic interests. For instance, the impact of remedial courses may differ depending on whether the student intended to major in a subject related to the field or not. On one

\footnotetext{
${ }^{23}$ Additional analysis ran separate regression models for each ACT score and compared the coefficients on the remediation dummy variable. These results reinforce the conclusions drawn from Table 5.
} 
hand, math remediation may send an especially influential signal to students intending to major in math-type courses that they will not succeed and should change to something different or dropout altogether. On the other hand, students intending to do math-type majors may view it as a necessary step and be especially motivated to succeed in the courses. Another question related to the issue is whether it makes sense to require math remediation for students not intending to major in mathrelated fields. Table 6 displays analyses of these questions by interacting the remediation variable with a dummy variable measuring students' pre-college interest in a related major. This information comes from the survey students fill out when taking the ACT, and so this variable is not influenced by their performance on the ACT or placement into or out of remediation. College majors have been categorized as a being generally math- or English-related for the analysis. ${ }^{24}$

As shown in the first row of each section of the table, remediation is estimated to have the same general effects. However, the second row of results displays that students needing math remediation who intended to major in a field related to math were more likely to complete their degrees within five years. However, these students did not necessarily major in a math-related subject. The last column examines the possible discouragement effect of remediation as the dependent variable measures whether students majored in a math-related subject. The coefficient on the dummy variable signifying pre-college interest in a math-related field suggests these students were much more likely to major in such a subject as expected. However, students who had math remediation were less likely to major in a math-related subject than their peers with similar interests. Similar results are found for students in English remediation. They were less likely to major in an English-related field than other students with similar pre-college interests. Therefore, although there is generally no difference in the effect of remediation on students by subject of interest, remediation seems to have a discouragement effect on major choice.

\footnotetext{
${ }^{24}$ The following are considered math-related majors: Mathematics, Statistics, Sciences (biology, chemistry, physics, etc.), Business, Computer Science, Engineering, and Architecture. The following are considered English-related majors: Humanities, Foreign Languages, Social Sciences, Journalism, Communications, Education, and Social Work. Students who did not declare a major in college are excluded from the analysis.
} 


\section{Conclusions}

In summary, we estimate that students in remediation have better educational outcomes in comparison to students with similar backgrounds and preparation who were not required to take the courses. While OLS estimates suggest remediation has a negative effect, once controlling for selection issues, the results become positive thereby emphasizing how inappropriate it is to simply compare the outcomes of remediated and non-remediated students. Instead, by exploiting institutional variation in remedial placement policies and the importance of proximity in college choice, our analysis provides plausible estimates of the causal effects of remediation. Over five years, math and English remediation are estimated to reduce the likelihood of dropping out and increase the likelihood of completing a degree. Moreover, English remediation appears to reduce the likelihood of transferring to a less selective or lower level college. Lending further support to the results, as theory would predict, the estimates are more positive for the LATE group than the general sample. Furthermore, as the definition of the LATE becomes more restrictive, the estimates continue to increase in size. While the LATE group is on the margin of needing remediation (i.e. they would be assigned to the classes at some schools while not at others), the results clearly suggest that remedial classes have beneficial effects for them.

While the sizes of the general results are similar for math and English remediation, once focusing on particular kinds of students, differences are found by remedial subject. The impact of math remediation appears to increase as the student's ACT increases across all of the outcomes. Meanwhile, the positive impact of English remediation increases with ACT score in terms of reducing the probability of stopping out, but it declines as ability increases for the other outcomes. In terms of student interests, math remediation increases the likelihood of degree completion among students intending to major in math-related fields though it slightly reduces the likelihood of majoring in such a field. English remediation is estimated to have a strong discouragement effect on students who intended to major in English-related fields. 
In conclusion, remediation is an important part of higher education, and it plays a very significant role in attempting to address the needs of the thousands of under-prepared students who enter postsecondary institutions each year. While we find it to have a positive impact on educational outcomes, further research is needed to more completely understand its other effects. By focusing on the LATE group, we do not investigate the effects of remediation on students who are extremely under-prepared for college-level work (i.e. we do not have an appropriate control group for them because they are nearly always in remediation regardless of the college they attend). Future analysis needs to establish the impact of remediation on this group of students. Additionally, while our results give a general sense of the impact of remediation, it may be the case that certain types of instruction and supports are more beneficial than others, and this should be investigated.

Additional research on how to maximize the benefits of remediation is essential as the cost of not offering the courses appears to be expensive. Our results suggest that under-prepared students without the courses are more likely to drop out of college and less likely to complete their degrees. Many sources document the higher incidence of unemployment, government dependency, and incarceration among individuals with less education, and the costs associated with these kinds of activities are large. Moreover, the increasing demands of the economy in terms of skill and international competition encourage the country to find an effective way to train its workers. As noted in a Time magazine article, eliminating remediation in higher education could "effectively end the American experiment with mass postsecondary education" (Cloud, 2002). With persistent concerns about the abilities of high school graduates, higher education must find ways to address the needs of under-prepared students.

\section{$\underline{\text { References }}$}

Avery, Chris and Thomas Kane (2004) "Student Perceptions of College Opportunities: The Boston COACH Program.” In Caroline Hoxby, ed. College Decisions: The New Economics of Choosing, Attending, and Completing College. 
Breneman, David W. and William N. Haarlow (1997) "Remedial Education: Costs and Consequences." Remediation in Higher Education. Washington, D.C.: Thomas B. Fordham Foundation.

Card, David (1995) "Using Geographic Variation in College Proximity to Estimate the Return to Schooling". In L.N.Christofides, E.K. Grant, and R. Swidinsky, editors, Aspects of Labor Market Behaviour: Essays in Honour of John Vanderkamp. Toronto: University of Toronto Press.

Cloud, (2002) "Who's ready for College." Time, vol. 160, issue 16, October 14.

Crowe, Edward (1998) "Statewide Remedial Education Policies—State Strategies that Support Successful Student Transitions from Secondary to Postsecondary Education.” Denver: SHEEO and ACT, Inc., September.

Greene, Jay and Greg Foster (2003) "Public High School Graduation and College Readiness Rates in the United States.” Manhattan Institute, Center for Civic Information, Education Working Paper, no. 3, September.

Hoyt, Jeff E. and Colleen T. Sorensen (1999) "Promoting Academic Standards?: The Link between Remedial Education in College and Student Preparation in High School.” Department of Institutional Research \& Management Studies, May.

Kane, Thomas (2003) “A Quasi-Experimental Estimate of the Impact of Financial Aid on CollegeGoing.” National Bureau of Economic Research Working Paper No. 9703.

Legislative Office of Education Oversight (1995) Remedial and Developmental Programs in Ohio's Public Colleges and Universities. Columbus: Ohio General Assembly.

Long, Bridget Terry (2004) "Does the Format of an Aid Program Matter? The Effect of In-Kind Tuition Subsidies." Review of Economics and Statistics.

Mortenson, Tom (2002) “Chance for College by Age 19 by State in 2000.” Oskaloosa, IA: Postsecondary Education OPPORTUNITY, no. 123, September. 
National Center for Education Statistics (1996) Descriptive summary of 1989-90 beginning postsecondary students: Five years later. Washington, DC: Office or Educational Research and Improvement.

National Center for Education Statistics (2003) Remedial Education at Degree-Granting Postsecondary Institutions in Fall 2000. Washington DC: Department of Education.

O’Hear, M., \& MacDonald, R. (1995). "A critical review of research in developmental education, Part I." Journal of Developmental Education, 19(2), 2-6.

Ohio Board of Regents (2001) Ohio Colleges and Universities 2001: Profile of Student Outcomes, Experiences and Campus Measures. Columbus, O.H.: Ohio Board of Regents.

Ohio Board of Regents (2002) Making the Transition from High School to College in Ohio 2002. Columbus, O.H.: Ohio Board of Regents.

Phipps, Ronald (1998) College Remediation - What it is, What it costs, What's at Stake. Washington, D.C.: Institute for Higher Education Policy.

Rosenbaum, James (2001) Beyond College for All. New York: Russell Sage Foundation.

Rouse, Cecilia (1995) "Democratization or Diversion? The Effect of Community Colleges on Educational Achievement." Journal of Business and Economic Statistics, vol. 13, no. 2, April, pp. 217-24.

Secondary and Higher Education Remediation Advisory Commission (1997) A Total Approach: Improving College Preparation in Ohio. Columbus: Ohio Board of Regents, June.

Sheehan, Robert (2002). Personal Communication, 18 September.

Soliday, Mary (2002) The Politics of Remediation. Pittsburgh: The University of Pittsburgh Press.

Trounson, Rebecca (2002) "Cal State Ouster Rate Rises Slightly.” The Los Angeles Times, Jan 31.

Weissman, Julie, Carol Rulakowski, and Marci Jumisko (1997) "Using Research to Evaluate Developmental Education Programs and Policies.” In Juan M. Ignash, ed. Implementing Effective Policies for Remedial and Developmental Education. New Directions for Community Colleges No. 100. San Francisco: Jossey-Bass Publishers. 
Figure 1: ACT Distributions by Institution
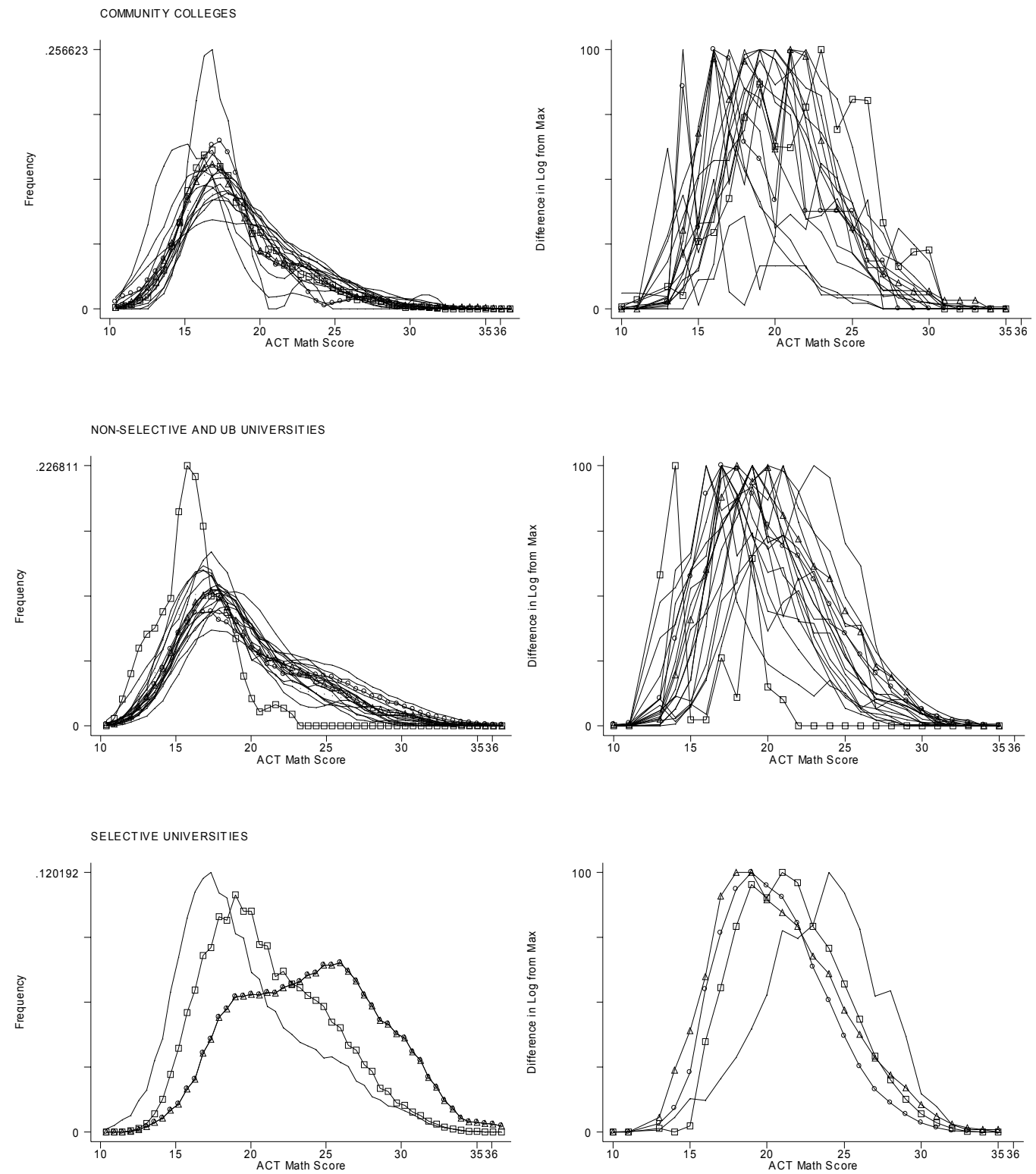

Notes: Each line represents a different institution. The graphs on the left are of the distribution of ACT scores. The graphs on the right show the likelihood of being placed in remediation for each ACT score. 
Table 1: First-time, Full-time Students in Ohio Public Colleges, Fall 1998

\begin{tabular}{|c|c|c|c|c|c|c|}
\hline & \multirow{2}{*}{$\begin{array}{l}\text { Full } \\
\text { Sample }\end{array}$} & \multicolumn{3}{|c|}{ Remedial Placement } & \multicolumn{2}{|c|}{$\begin{array}{l}\text { Local Average Treatment Effect } \\
\text { (LATE) Sample for Analysis }\end{array}$} \\
\hline & & $\begin{array}{c}\text { No } \\
\text { Remediation }\end{array}$ & $\begin{array}{c}\text { In Math } \\
\text { Remediation }\end{array}$ & $\begin{array}{l}\text { In English } \\
\text { Remediation }\end{array}$ & Math Sample & English Sample \\
\hline \multicolumn{7}{|c|}{ Demographics and Achievement } \\
\hline Female & 0.5569 & 0.5560 & 0.5940 & 0.4729 & 0.5815 & 0.5207 \\
\hline Black & 0.0719 & 0.0452 & 0.1422 & 0.1854 & 0.0846 & 0.1009 \\
\hline Hispanic & 0.0164 & 0.0140 & 0.0258 & 0.0221 & 0.0179 & 0.0201 \\
\hline Asian & 0.0184 & 0.0212 & 0.0095 & 0.0122 & 0.0131 & 0.0172 \\
\hline $\begin{array}{l}\text { ACT Overall Score } \\
(36 \text { maximum) }\end{array}$ & $\begin{array}{l}21.92 \\
(4.30)\end{array}$ & $\begin{array}{l}23.37 \\
(3.84)\end{array}$ & $\begin{array}{l}18.26 \\
(3.03)\end{array}$ & $\begin{array}{l}17.21 \\
(2.77)\end{array}$ & $\begin{array}{l}20.36 \\
(3.23)\end{array}$ & $\begin{array}{l}19.77 \\
(3.52)\end{array}$ \\
\hline \multicolumn{7}{|c|}{ Math Preparation and Achievement } \\
\hline $\begin{array}{l}\text { ACT Math Score } \\
(36 \text { maximum) }\end{array}$ & $\begin{array}{l}21.74 \\
(4.78)\end{array}$ & $\begin{array}{l}23.32 \\
(4.43)\end{array}$ & $\begin{array}{l}17.38 \\
(2.65)\end{array}$ & --- & $\begin{array}{l}19.67 \\
(3.08)\end{array}$ & --- \\
\hline $\begin{array}{l}\text { Grades in High School } \\
\text { Math }\end{array}$ & $\begin{array}{l}3.06 \\
(0.75)\end{array}$ & $\begin{array}{c}3.26 \\
(0.65)\end{array}$ & $\begin{array}{c}2.51 \\
(0.74)\end{array}$ & --- & $\begin{array}{c}2.89 \\
(0.69)\end{array}$ & --- \\
\hline \multicolumn{7}{|c|}{ English Preparation and Achievement } \\
\hline $\begin{array}{l}\text { ACT English Score } \\
\text { ( } 36 \text { maximum) }\end{array}$ & $\begin{array}{l}21.25 \\
(4.93)\end{array}$ & $\begin{array}{l}22.77 \\
(4.43)\end{array}$ & --- & $\begin{array}{l}15.77 \\
(3.38)\end{array}$ & --- & $\begin{array}{l}18.64 \\
(3.98)\end{array}$ \\
\hline $\begin{array}{l}\text { ACT Reading Score } \\
\text { ( } 36 \text { maximum) }\end{array}$ & $\begin{array}{l}22.28 \\
(5.59)\end{array}$ & $\begin{array}{l}23.78 \\
(5.22)\end{array}$ & --- & $\begin{array}{l}16.85 \\
(4.06)\end{array}$ & --- & $\begin{array}{l}19.69 \\
(4.74)\end{array}$ \\
\hline $\begin{array}{l}\text { Grades in High School } \\
\text { English }\end{array}$ & $\begin{array}{c}3.23 \\
(0.68)\end{array}$ & $\begin{array}{c}3.38 \\
(0.57)\end{array}$ & --- & $\begin{array}{c}2.75 \\
(0.63)\end{array}$ & --- & $\begin{array}{c}3.04 \\
(0.64)\end{array}$ \\
\hline \multicolumn{7}{|c|}{ College of Attendance and Outcomes } \\
\hline Attend Selective 4yr & 0.5369 & 0.6438 & 0.2649 & 0.2099 & 0.4633 & 0.4431 \\
\hline Attend Nonselective $4 \mathrm{yr}$ & 0.3581 & 0.3063 & 0.4634 & 0.5304 & 0.4079 & 0.4155 \\
\hline Attend Comm. College & 0.1049 & 0.0500 & 0.2717 & 0.2598 & 0.1287 & 0.1413 \\
\hline Math Remediation & 0.2237 & 0.00 & 1.00 & 0.5779 & 0.2925 & 0.3177 \\
\hline English Remediation & 0.1405 & 0.00 & 0.3608 & 1.00 & 0.1741 & 0.2249 \\
\hline $\begin{array}{l}\text { Dropped Out before } \\
\text { Spring } 2003\end{array}$ & 0.4005 & 0.3082 & 0.6519 & 0.6680 & 0.4685 & 0.4773 \\
\hline Total Credit Hours & 81.20 & 91.10 & 54.97 & 51.47 & 72.39 & 75.95 \\
\hline $\begin{array}{l}\text { Completed BA/BS } \\
\text { degree within } 5 \text { yrs }\end{array}$ & 0.4361 & 0.5334 & 0.1810 & 0.1492 & 0.3525 & 0.3546 \\
\hline Observations & 28,376 & 20,332 & 6349 & 4250 & 18,917 & 15,013 \\
\hline
\end{tabular}

Notes: Standard deviations are shown in the parentheses. The number of observations for variables with less than the total observations is shown in brackets. Sample is restricted to traditional-aged (18-20), first-time students who entered full-time in Fall 1998 and had valid zip code information. Students are considered to have "Dropped Out" if they have not completed a bachelor's degree and are nowhere in the Ohio public higher education system in Spring 2003 (after five years). "Transfer Up" is defined transferring to a more nonselective or higher level college while "Transfer Down" is the reverse. 
Table 2: Example of the Construction of the Instrument using a Sample Student

\begin{tabular}{|c|c|c|c|}
\hline \multirow[t]{2}{*}{ College Campus } & $\begin{array}{l}\text { Predicted Probability of } \\
\text { Enrollment given Distance }\end{array}$ & $\begin{array}{l}\text { Predicted Probability of Math } \\
\text { Remediation if Attend College }\end{array}$ & Column $1 *$ Column 2 \\
\hline & (1) & (2) & (3) \\
\hline 1 & .0000322 & .0214147 & .0000007 \\
\hline 2 & .0041706 & .1407967 & .0005872 \\
\hline 3 & .0702409 & .2123963 & .0149189 \\
\hline 4 & .0000011 & .6154543 & .0000007 \\
\hline 5 & .0000011 & .6019241 & .0000007 \\
\hline 6 & .0000011 & .7366664 & .0000008 \\
\hline 7 & .0021548 & .2368569 & .0005104 \\
\hline 8 & .0033154 & .2448504 & .0008118 \\
\hline 9 & .1448748 & .1591497 & .0230568 \\
\hline 10 & .0002561 & .2801378 & .0000717 \\
\hline 11 & .1737791 & .0303145 & .0052680 \\
\hline 12 & .0032035 & .8401513 & .0026914 \\
\hline 13 & .0000017 & .1572767 & .0000003 \\
\hline 14 & .0000212 & .5702834 & .0000121 \\
\hline 15 & .0035474 & .7567446 & .0026845 \\
\hline 16 & .0000004 & .2208170 & .0000001 \\
\hline 17 & .0024863 & .0000950 & .0000002 \\
\hline 18 & .0015160 & .1478897 & .0002242 \\
\hline 19 & .0000050 & .4503805 & .0000023 \\
\hline 20 & .0032313 & .2508281 & .0008105 \\
\hline 21 & .0000004 & .2624444 & .0000001 \\
\hline 22 & .0032040 & .3407020 & .0010916 \\
\hline 23 & .1196565 & .0433224 & .0051838 \\
\hline 24 & .0091963 & .6631163 & .0060982 \\
\hline 25 & .0002830 & .2911467 & .0000824 \\
\hline 26 & .0000048 & .4136842 & .0000020 \\
\hline 27 & .0007260 & .2317703 & .0001683 \\
\hline 28 (attended) & .1714355 & .1026604 & .0175996 \\
\hline 29 & .0693176 & .1118652 & .0077542 \\
\hline 30 & .0001288 & .3324531 & .0000428 \\
\hline 31 & .0000060 & .4262620 & .0000025 \\
\hline 32 & .0000340 & .5179935 & .0000176 \\
\hline 33 & .0136011 & .0167948 & .0002284 \\
\hline 34 & .0207147 & .3456770 & .0071606 \\
\hline 35 & .0008362 & .0000000 & .0000000 \\
\hline 36 & .0008362 & .0009789 & .0000008 \\
\hline 37 & .0008362 & .0000055 & .0000000 \\
\hline 38 & .0000268 & .1431467 & .0000038 \\
\hline 39 & .0070355 & .3050195 & .0021460 \\
\hline 40 & .0000113 & .0719892 & .0000008 \\
\hline 41 & .0000143 & .2834351 & .0000041 \\
\hline 42 & .0000012 & .0955865 & .0000001 \\
\hline 43 & .1255224 & .1086463 & .0136375 \\
\hline 44 & .0435922 & .2501734 & .0109056 \\
\hline 45 & .0001392 & .1497208 & .0000208 \\
\hline \multicolumn{3}{|c|}{ Instrument $=$ Weighted Average of Remediation Probabilities $=$ Sum of Column 3} & 0.1238 \\
\hline
\end{tabular}


Table 3: Effect of MATH Remediation - Full Sample versus the Local Average Treatment Effect

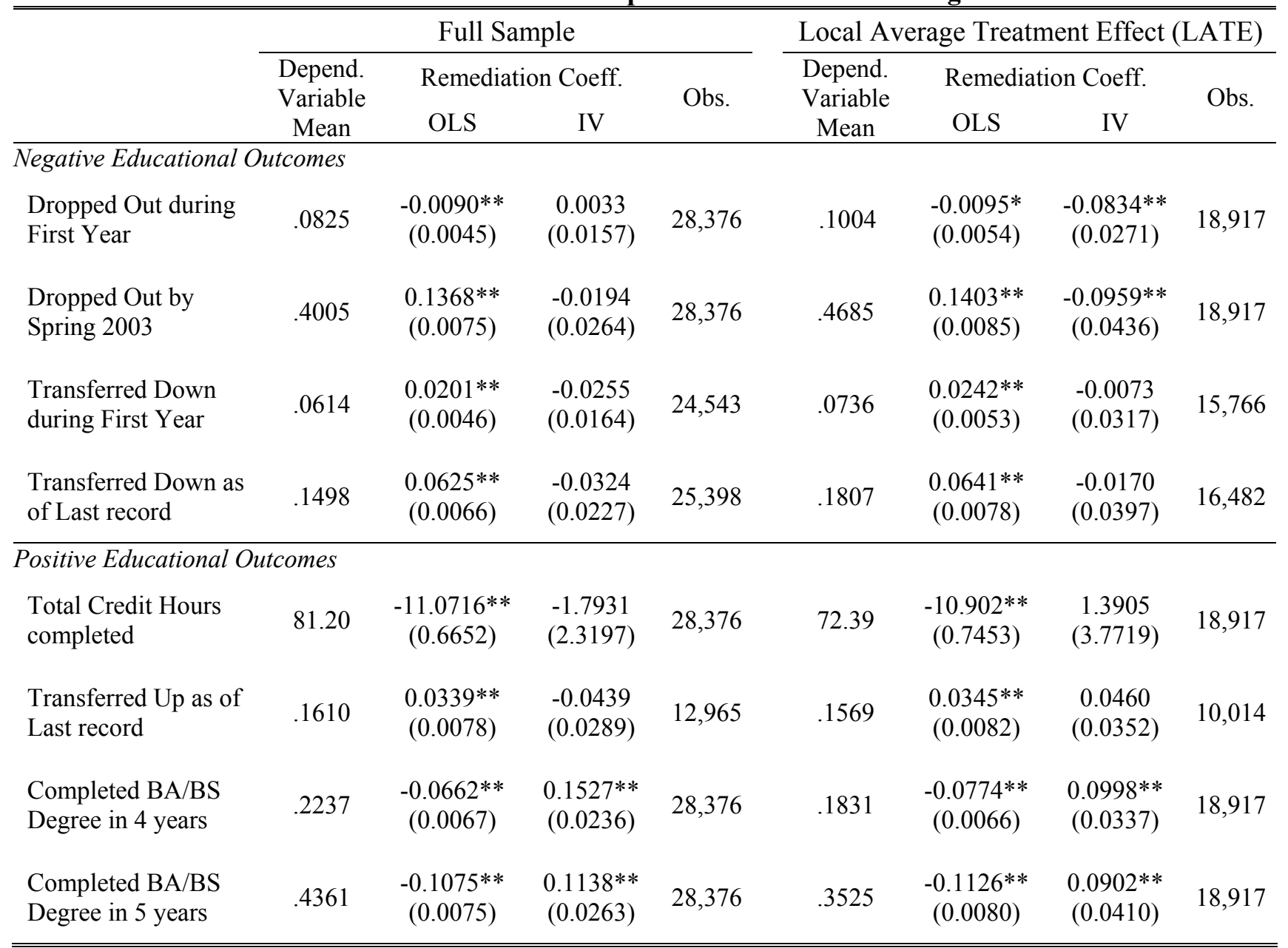

** Significant at the $5 \%$ level

* Significant at the $10 \%$ level

Notes: Each coefficient under the OLS and IV columns represents a separate regression with controls for race, gender, age, ACT composite score, ACT math score, high school GPA, high school rank, family income, high school type, semesters of high school math, high school grades in math, and type of high school degree (dummy variable for GED). Standard errors are shown in the parentheses. Students are considered "dropouts" if they are no longer at any public, Ohio college at the end of the time period and have not received a Bachelor's degree. Students who "transferred down" were at a less selective or lower-level college as of their last enrollment record. Students who have "transferred up" went to a higher-level college or more selective college. 
Table 4: Effect of ENGLISH Remediation - Full Sample versus the Local Average Treatment Effect

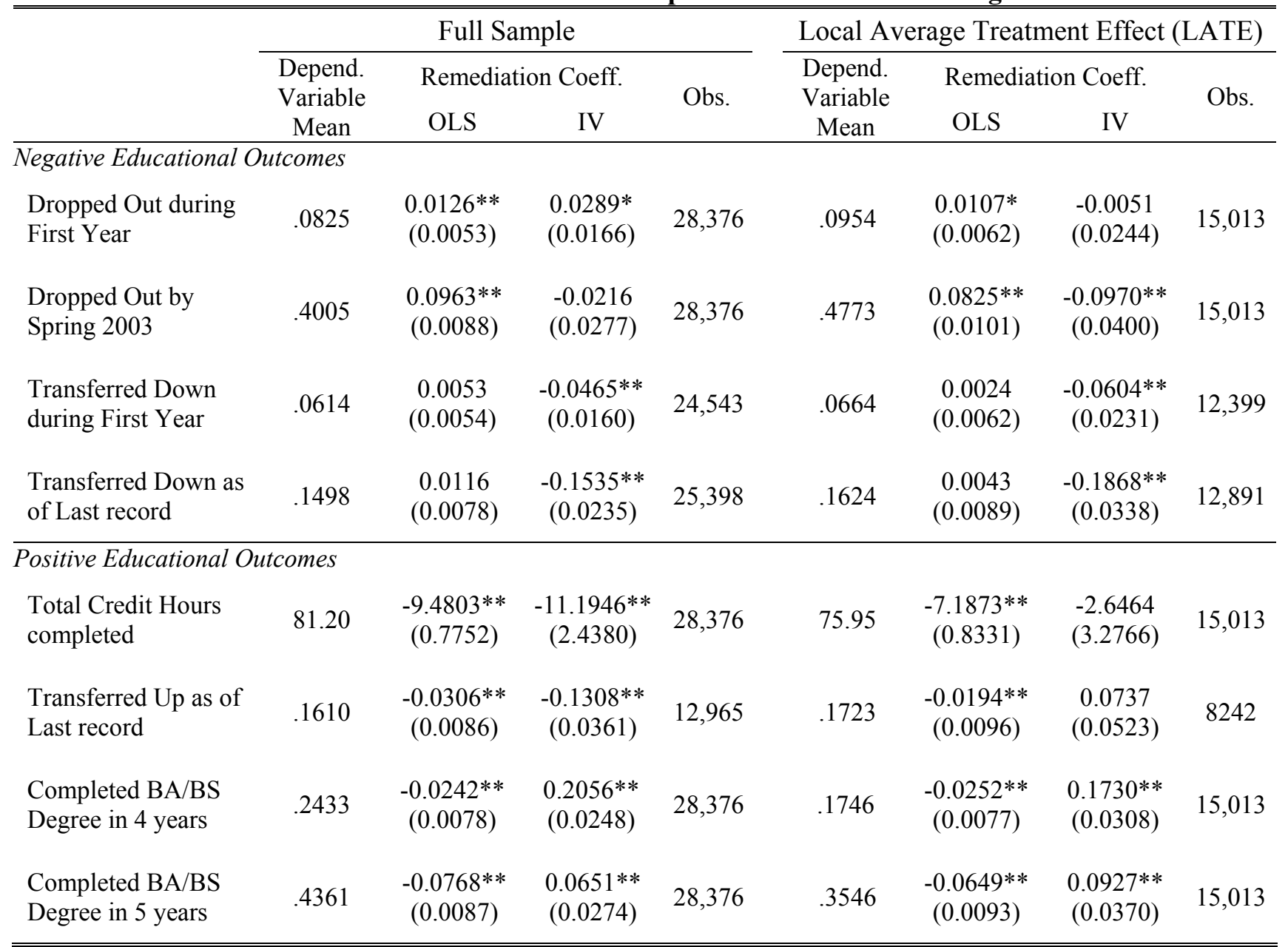

** Significant at the $5 \%$ level

* Significant at the $10 \%$ level

Notes: Each coefficient under the OLS and IV columns represents a separate regression with controls for race, gender, age, ACT composite score, ACT English score, ACT Reading score, high school GPA, high school rank, family income, high school type, semesters of high school English, high school grades in English, and type of high school degree (dummy variable for GED). Standard errors are shown in the parentheses. Students are considered "dropouts" if they are no longer at any public, Ohio college at the end of the time period and have not received a Bachelor's degree. Students who "transferred down" were at a less selective or lower-level college as of their last enrollment record. Students who have "transferred up" went to a higher-level college or more selective college. 
Table 5: IV LATE Estimates - Interactions with ACT Score

\begin{tabular}{lccccc}
\hline \hline & $\begin{array}{c}\text { Dropped Out by } \\
\text { Spring 2003 }\end{array}$ & $\begin{array}{c}\text { Transferred } \\
\text { Down as of Last } \\
\text { record }\end{array}$ & $\begin{array}{c}\text { Total Credit } \\
\text { Hours }\end{array}$ & $\begin{array}{c}\text { Transferred Up } \\
\text { as of Last record }\end{array}$ & $\begin{array}{c}\text { Completed } \\
\text { BAS Degree in } \\
5 \text { years }\end{array}$ \\
\hline \hline A. MATH REMEDIATION & $(1)$ & $(2)$ & $(3)$ & $(4)$ & $(5)$ \\
Effect of Remediation & $0.2879^{* *}$ & $0.3999^{* *}$ & $-64.3993^{* *}$ & $-0.2533^{* *}$ & $-0.4907^{* *}$ \\
& $(0.1167)$ & $(0.1089)$ & $(10.2201)$ & $(0.1073)$ & $(0.1109)$ \\
Remediation * ACT & $-0.0242^{* *}$ & $-0.0263^{* *}$ & $4.1933^{* *}$ & $0.0184^{* *}$ & $0.0368^{* *}$ \\
Math Score & $(0.0074)$ & $(0.0071)$ & $(0.6511)$ & $(0.0060)$ & $(0.0071)$ \\
& $-0.0172^{* *}$ & 0.0001 & $0.7901^{* *}$ & -0.0007 & $0.0131^{* *}$ \\
ACT Math Score & $(0.0025)$ & $(0.0021)$ & $(0.2217)$ & $(0.0026)$ & $(0.0024)$ \\
& 18,917 & 16,482 & 18,917 & 10,014 & 18,917 \\
Observations & .4685 & .1807 & 72.39 & .1569 & .3525 \\
Dependent Var. Mean & $(6)$ & $(7)$ & $(8)$ & $(9)$ & $(10)$ \\
\hline \hline & & & & $0.1874^{* *}$ \\
B. ENGLISH REMEDIATION & $0.2039^{* *}$ & -0.0468 & $39.8370^{* *}$ & $0.4095^{* *}$ & $(0.0793)$ \\
Effect of Remediation & $(0.0869)$ & $(0.0826)$ & $(7.1747)$ & $(0.0869)$ & $-0.0114^{*}$ \\
Remediation * ACT & $-0.0205^{* *}$ & -0.0077 & $-3.8338^{* *}$ & $-0.0316^{* *}$ & $(0.0059)$ \\
English Score & $(0.0064)$ & $(0.0060)$ & $(0.5306)$ & $(0.0058)$ & $0.0232^{* *}$ \\
ACT English Score & $-0.0171^{* *}$ & $-0.0120^{* *}$ & $2.4964^{* *}$ & $0.0162^{* *}$ & $(0.0016)$ \\
Observations & $(0.0017)$ & $(0.0014)$ & $(0.1432)$ & $(0.0024)$ & 15,013 \\
Dependent Var. Mean & 15,013 & 12,891 & 15,013 & 8242 & .3546 \\
\hline \hline
\end{tabular}

** Significant at the $5 \%$ level * Significant at the $10 \%$ level

Notes: Each specification represents a separate regression with controls for race, gender, age, ACT composite score, ACT math (or English and Reading) score, high school GPA, high school rank, family income, high school type, years of high school math (or English), high school grades in math (or English), and type of high school degree (dummy variable for GED). Standard errors are shown in the parentheses. Students are considered "dropouts" if they are no longer at any public, Ohio college at the end of the time period and have not received a Bachelor's degree. Students who "transferred down" were at a less selective or lower-level college as of their last enrollment record. Students who have "transferred up" went to a higher-level college or more selective college. 
Table 6: IV LATE Estimates of the Impact of Remediation by Pre-College Plan of Study

\begin{tabular}{|c|c|c|c|c|c|c|}
\hline & $\begin{array}{c}\text { Dropped Out } \\
\text { by Spring } \\
2003 \\
\end{array}$ & $\begin{array}{l}\text { Transferred } \\
\text { Down as of } \\
\text { Last record }\end{array}$ & $\begin{array}{l}\text { Total Credit } \\
\text { Hours }\end{array}$ & $\begin{array}{c}\text { Transferred } \\
\text { Up as of Last } \\
\text { record } \\
\end{array}$ & $\begin{array}{c}\text { Completed } \\
\text { Degree in } 5 \\
\text { years }\end{array}$ & $\begin{array}{c}\text { Choose Major } \\
\text { in Field of } \\
\text { Interest } \\
\end{array}$ \\
\hline & (1) & (2) & (3) & (4) & (5) & (6) \\
\hline \multicolumn{7}{|c|}{ A. MATH REMEDIATION } \\
\hline Remediation & $\begin{array}{c}-0.1025^{* *} \\
(0.0453)\end{array}$ & $\begin{array}{l}-0.0102 \\
(0.0412)\end{array}$ & $\begin{array}{c}1.1131 \\
(3.9161)\end{array}$ & $\begin{array}{c}0.0519 \\
(0.0366)\end{array}$ & $\begin{array}{l}0.0782 * \\
(0.0426)\end{array}$ & $\begin{array}{c}0.0519 \\
(0.0412)\end{array}$ \\
\hline $\begin{array}{l}\text { Remediation * } \\
\text { Pre-college interest in } \\
\text { Math-Related Field }\end{array}$ & $\begin{array}{c}0.0245 \\
(0.0329)\end{array}$ & $\begin{array}{l}-0.0274 \\
(0.0307)\end{array}$ & $\begin{array}{c}1.6504 \\
(2.8428)\end{array}$ & $\begin{array}{l}-0.0195 \\
(0.0327)\end{array}$ & $\begin{array}{l}0.0584^{*} \\
(0.0309)\end{array}$ & $\begin{array}{c}-0.0835^{* *} \\
(0.0303)\end{array}$ \\
\hline $\begin{array}{l}\text { Pre-college interest in } \\
\text { Math-Related Field }\end{array}$ & $\begin{array}{l}-0.0019 \\
(0.0123)\end{array}$ & $\begin{array}{c}0.0046 \\
(0.0100)\end{array}$ & $\begin{array}{l}-1.6438 \\
(1.0652)\end{array}$ & $\begin{array}{l}-0.0035 \\
(0.0147)\end{array}$ & $\begin{array}{c}-0.0384^{* *} \\
(0.0116)\end{array}$ & $\begin{array}{c}0.3254 * * \\
(0.0112)\end{array}$ \\
\hline Observations & 18,917 & 16,482 & 18,917 & 10,014 & 18,917 & 17,643 \\
\hline Dependent Var. Mean & .4685 & 1807 & 72.39 & 1569 & .3525 & 2792 \\
\hline & (7) & (8) & (9) & (10) & (11) & (12) \\
\hline \multicolumn{7}{|c|}{ B. ENGLISH REMEDIATION } \\
\hline Remediation & $\begin{array}{c}-0.1002 * * \\
(0.0408)\end{array}$ & $\begin{array}{c}-0.1882 * * \\
(0.0346)\end{array}$ & $\begin{array}{l}-1.9361 \\
(3.3419)\end{array}$ & $\begin{array}{l}0.0873 * \\
(0.0525)\end{array}$ & $\begin{array}{l}0.1042 * * \\
(0.0377)\end{array}$ & $\begin{array}{l}0.0907 * * \\
(0.0401)\end{array}$ \\
\hline $\begin{array}{l}\text { Remediation * } \\
\text { Pre-college interest in } \\
\text { English-Related Field }\end{array}$ & $\begin{array}{c}0.0134 \\
(0.0429)\end{array}$ & $\begin{array}{c}0.0033 \\
(0.0395)\end{array}$ & $\begin{array}{l}-2.9881 \\
(3.5128)\end{array}$ & $\begin{array}{l}-0.0472 \\
(0.0475)\end{array}$ & $\begin{array}{l}-0.0485 \\
(0.0397)\end{array}$ & $\begin{array}{c}-0.2235^{* *} \\
(0.0416)\end{array}$ \\
\hline $\begin{array}{l}\text { Pre-college interest in } \\
\text { English-Related Field }\end{array}$ & $\begin{array}{l}-0.0195 \\
(0.0129)\end{array}$ & $\begin{array}{l}-0.0146 \\
(0.0105)\end{array}$ & $\begin{array}{l}3.4901 * * \\
(1.0530)\end{array}$ & $\begin{array}{l}0.0408 * * \\
(0.0175)\end{array}$ & $\begin{array}{c}0.0485^{* *} \\
(0.0119)\end{array}$ & $\begin{array}{c}0.3337 * * \\
(0.0121)\end{array}$ \\
\hline Observations & 15,013 & 12,891 & 15,013 & 8242 & 15,013 & 14,066 \\
\hline Dependent Var. Mean & .4773 & .1624 & 75.95 & .1723 & .3546 & .2866 \\
\hline
\end{tabular}

** Significant at the $5 \%$ level * Significant at the $10 \%$ level

Notes: Each specification represents a separate regression with controls for race, gender, age, ACT composite score, ACT math (or English and Reading) score, high school GPA, high school rank, family income, high school type, years of high school math (or English), high school grades in math (or English), and type of high school degree (dummy variable for GED). Standard errors are shown in the parentheses. Students are considered "dropouts" if they are no longer at any public, Ohio college at the end of the time period and have not received a Bachelor's degree. Students who "transferred down" were at a less selective or lower-level college as of their last enrollment record. Students who have "transferred up" went to a higher-level college or more selective college. The following are considered math-related majors: Mathematics, Statistics, Sciences (biology, chemistry, physics, etc.), Business, Computer Science, Engineering, and Architecture. The following are considered English-related majors:

Humanities, Foreign Languages, Social Sciences, Journalism, Communications, Education, and Social Work. Students who did not declare a major in college are excluded from the analysis. 
Appendix Table 1: Local High School and Community Characteristics and Remediation Cutoffs Dependent Variable: Percentile of the Estimated ACT Cutoff for Remediation (OLS estimates)

\begin{tabular}{|c|c|c|c|c|}
\hline \multirow[b]{2}{*}{ Radius of Sample } & \multicolumn{2}{|c|}{ All Nearby High Schools } & \multicolumn{2}{|c|}{$\begin{array}{c}\text { Nearby HS with fewer than } 50 \% \text { Pas } \\
12^{\text {th }} \text { Grade Math Exam }\end{array}$} \\
\hline & $\begin{array}{l}10 \text { Miles } \\
(1)\end{array}$ & $\begin{array}{l}30 \text { Miles } \\
\text { (2) }\end{array}$ & $\begin{array}{l}10 \text { Miles } \\
\text { (3) }\end{array}$ & $\begin{array}{l}30 \text { Miles } \\
(4)\end{array}$ \\
\hline \multicolumn{5}{|l|}{ University Characteristics } \\
\hline University Branch & $\begin{array}{c}3.01 \\
(10.45)\end{array}$ & $\begin{array}{l}-3.55 \\
(9.91)\end{array}$ & $\begin{array}{c}-6.86 \\
(12.61)\end{array}$ & $\begin{array}{l}-1.03 \\
(9.19)\end{array}$ \\
\hline State Community College & $\begin{array}{c}7.55 \\
(10.47)\end{array}$ & $\begin{array}{c}8.28 \\
(10.95)\end{array}$ & $\begin{array}{c}7.04 \\
(12.86)\end{array}$ & $\begin{array}{c}12.37 \\
(10.00)\end{array}$ \\
\hline Local Community College & $\begin{array}{c}8.42 \\
(11.66)\end{array}$ & $\begin{array}{c}6.52 \\
(12.34)\end{array}$ & $\begin{array}{c}4.67 \\
(14.98)\end{array}$ & $\begin{array}{c}6.65 \\
(11.55)\end{array}$ \\
\hline Technical College & $\begin{array}{c}2.67 \\
(10.81)\end{array}$ & $\begin{array}{l}-2.60 \\
(12.40)\end{array}$ & $\begin{array}{c}1.94 \\
(14.15)\end{array}$ & $\begin{array}{c}1.61 \\
(11.45)\end{array}$ \\
\hline Selective Admissions & $\begin{array}{c}13.89 \\
(11.10)\end{array}$ & $\begin{array}{l}18.21^{*} \\
(10.24)\end{array}$ & $\begin{array}{c}21.36 \\
(12.54)\end{array}$ & $\begin{array}{l}19.24^{*} \\
(9.69)\end{array}$ \\
\hline Degree of Urbanization & $\begin{array}{l}-0.88 \\
(2.60)\end{array}$ & $\begin{array}{l}-1.15 \\
(2.50)\end{array}$ & $\begin{array}{l}-0.30 \\
(3.13)\end{array}$ & $\begin{array}{l}-0.73 \\
(2.52)\end{array}$ \\
\hline $\begin{array}{l}\text { College Percent African- } \\
\text { American }\end{array}$ & $\begin{array}{c}0.65 \\
(1.32)\end{array}$ & $\begin{array}{l}1.03 \\
(0.90)\end{array}$ & $\begin{array}{c}1.47 \\
(1.39)\end{array}$ & $\begin{array}{c}1.21 \\
(0.85)\end{array}$ \\
\hline College Percent Hispanic & $\begin{array}{l}-7.25 \\
(5.69)\end{array}$ & $\begin{array}{l}-1.00 \\
(3.68)\end{array}$ & $\begin{array}{l}-3.51 \\
(6.30)\end{array}$ & $\begin{array}{l}-1.95 \\
(3.62)\end{array}$ \\
\hline \multicolumn{5}{|c|}{ Local High School and District Characteristics } \\
\hline Pct. Free Lunch at the HS & $\begin{array}{l}-19.52 \\
(90.69)\end{array}$ & $\begin{array}{l}29.50 \\
(216.2)\end{array}$ & $\begin{array}{l}-16.06 \\
(87.43)\end{array}$ & $\begin{array}{c}225.11 \\
(169.31)\end{array}$ \\
\hline $\begin{array}{l}1995 \text { Median District Income } \\
(000 \mathrm{~s})\end{array}$ & $\begin{array}{c}1.04 \\
(2.32)\end{array}$ & $\begin{array}{c}0.20 \\
(3.48)\end{array}$ & $\begin{array}{l}2.67 \\
(2.84)\end{array}$ & $\begin{array}{c}4.04 \\
(3.53)\end{array}$ \\
\hline $\begin{array}{l}\text { HS Percent African- } \\
\text { American }\end{array}$ & $\begin{array}{l}20.85 \\
(79.96)\end{array}$ & $\begin{array}{l}-14.27 \\
(138.9)\end{array}$ & $\begin{array}{c}-7.77 \\
(55.38)\end{array}$ & $\begin{array}{l}-18.42 \\
(77.66)\end{array}$ \\
\hline HS Percent Hispanic & $\begin{array}{c}492.0 \\
(338.3)\end{array}$ & $\begin{array}{c}154.8 \\
(331.6)\end{array}$ & $\begin{array}{c}231.9 \\
(334.7)\end{array}$ & $\begin{array}{l}-117.5 \\
(206.6)\end{array}$ \\
\hline $\begin{array}{l}\text { Mean HS Math Pass } \\
\text { percentage }\end{array}$ & $\begin{array}{c}0.52 \\
(0.93)\end{array}$ & $\begin{array}{c}0.52 \\
(1.10)\end{array}$ & $\begin{array}{l}-0.44 \\
(1.28)\end{array}$ & $\begin{array}{l}-0.31 \\
(1.61)\end{array}$ \\
\hline $\begin{array}{l}\text { HS Dropout Rate (3-year } \\
\text { average) }\end{array}$ & $\begin{array}{l}-0.21 \\
(0.84)\end{array}$ & $\begin{array}{l}-0.91 \\
(1.44)\end{array}$ & $\begin{array}{l}-0.37 \\
(0.73)\end{array}$ & $\begin{array}{l}-1.99 \\
(1.36)\end{array}$ \\
\hline $\begin{array}{l}\text { HS } 1997 \text { Instructional } \\
\text { Expend/Stud (000s) }\end{array}$ & $\begin{array}{l}-8.35 \\
(9.64)\end{array}$ & $\begin{array}{c}-3.41 \\
(19.93)\end{array}$ & $\begin{array}{c}0.37 \\
(10.80)\end{array}$ & $\begin{array}{l}-14.32 \\
(19.64)\end{array}$ \\
\hline Number of Local HS & $\begin{array}{c}1.82 \\
(1.97)\end{array}$ & $\begin{array}{l}-0.87 \\
(0.73)\end{array}$ & $\begin{array}{c}0.37 \\
(2.93)\end{array}$ & $\begin{array}{l}-2.31 \\
(1.70)\end{array}$ \\
\hline $\begin{array}{l}\text { Number of Local HS } \\
\text { Students (000s) }\end{array}$ & $\begin{array}{l}-19.52 \\
(90.69)\end{array}$ & $\begin{array}{l}29.50 \\
(216.2)\end{array}$ & $\begin{array}{l}-16.06 \\
(87.43)\end{array}$ & $\begin{array}{c}225.11 \\
(169.31)\end{array}$ \\
\hline $\begin{array}{l}\text { Observations } \\
\text { R-squared }\end{array}$ & $\begin{array}{c}42 \\
0.4201\end{array}$ & $\begin{array}{c}42 \\
0.3221\end{array}$ & $\begin{array}{c}38 \\
0.3191\end{array}$ & $\begin{array}{c}42 \\
0.4025\end{array}$ \\
\hline
\end{tabular}

** Significant at the $5 \%$ level * Significant at the $10 \%$ level

Sample: Public and private high schools and school districts within 10 or 30 miles of a public Ohio college.

Notes: Standard errors shown in parentheses. Variable means are weighted by the enrollment of the school or district. The percentile is the 1999 percentile among ACT test-takers nationally. The results do not change in statistical significance if the ACT cutoff score or the natural log of the score is used. 